\title{
PELIMPAHAN WEWENANG PENGAWASAN TAMBANG GALIAN C OLEH PEMERINTAH KAB GRESIK
}

\author{
Oleh : \\ Dwi Wachidiyah Ningsih*, Andie Achmad Febryanto** \\ * Fakultas Hukum, Universitas Gresik \\ Email : dwiwachidiyah24@gmail.com \\ **Fakultas Hukum Universitas Gresik \\ Email : andie.febryanto@gmail.com
}

\begin{abstract}
ABSTRAK
Penelitian ini berjudul tentang pengawasan tambang galian c di KabupatenGresik ditinjau dari pasal 14 ayat (1) Undang-Undang Nomor 23 Tahun 2014. Permasalahan yang dibahas dalam penelitian ini adalah bagaimana wewenang pemerintah Kabupaten atas tambang galian $\mathrm{c}$ wilayah Kabupaten Gresik dan siapa yang bertanggung jawab kerusakan lingkungan atas aktivitas tambang galian c di wilayah Kabupaten Gresik. Berlakunya Undang-Undang Nomor 23 Tahun 2014 Tentang Pemerintah Daerah, memberikan kewenangan pengelolaan sumber daya khususnya pertambangan kepada pemerintah pusat dan pemerintah Provinsi. Provinsi memegang kendali atas izin dan pengawasan terhadap galian c. Jenis penelitian yang digunakan dalam penelitian ini menggunakan penelitian normatif. Penelitian hukum Normatif adalah penelitian hukum untuk menemukan aturan hukum, prinsip-prinsip hukum, maupun doktrin-doktrin hukum guna menjawab issu hukum yang dihadapi. Berdasarkan hasil analisis yang membahas pokok- pokok permasalahan diatas, penulis dapat memberikan kesimpulan bahwa berlakunya Undang-Undang Nomor 23 Tahun 2014 Tentang Pemerintah Daerah menyebabkan terjadinya pergeseran kewenangan terkait penerbitan izin usaha pertambangan dan pengawasan terhadap kegiatan pertambangan. Kewenangan yang semula dipegang penuh oleh Kabupaten/Kota kini dipegang oleh Pemerintah Provinsi. Maka saran yang dapat penulis berikan adalah penarikan kewenangan yang dilakukan harusnya tidak sampai ditingkat pengawasan dan penindakan. Pengawasan dan penindakan lebih baiknya berada pada wilayah Pemerintah Kabupaten/Kota karena akan mempercepat aksi untuk penindakan terhadap pelanggar.
\end{abstract}

Kata kunci : Izin, Pertambangan, Pengawasan. 


\begin{abstract}
This research entitled about the supervision of the $C$ quarry in Gresik Regency in terms of Article 14 paragraph (1) constitution number 23 of 2014. The problems discussed in this study are how is the authority of the regency government over quarrying $C$ Gresik regency area and who is responsible for environmental damage for mining $c$ activities in the Gresik Regency. Entry into force constitution number 23 of 2014 abaout local government, give the authority to manage resources especially mining to the central government and provincial governments. The province has control over permits and supervision of excavation $C$. This type of research used in this study uses normative research. Normative Legal Research to determine legal, legal principles, and legal doctrines in order to answer legal issues faced. Based on the results of the analysis that discusses the main issues above, the author can conclude that the entry into force of the constitution number 23 of 2014 about local government causes it to happen a shift in authority related to the issuance of mining business permits and supervision of mining activities. Authority that was previously fully held by the regency / city is now vested in the provincial government. Then the goal that the writer can give is that the withdrawal of authority that is carried out should not be up to the level of supervision and action. It is better if supervision and prosecution is in the area of the regency/city government because it can accelerate action to take action take action against offenders.
\end{abstract}

Key word: Mining, permition, supervision

\section{A. PENDAHULUAN}

\section{Latar Belakang}

Indonesia merupakan negara yang kaya akan sumber daya alamnya. Mineral dan batu bara merupakan kekayaan alam yang tak luput dari kehidupan kita sehari-hari. Hasil kekayaan alam tersebut merupakan salah satu sumber penting dalam memenuhi perekonomian hidup orang banyak oleh karena itu sumber daya alam harus dikelola dengan baik agar kedepannya bermanfaat bagi perekonomian daerah serta nasioanal dalam mencapai kemakmuran dan kesejahteraan masyarakat secara adil. Pasal 33 ayat (3) UndangUndang Dasar 1945 (untuk selanjutnya disebut UUD '45) menyatakan bahwa bumi dan air dan kekayaan alam yang terkandung di dalamnya dikuasai oleh negara dan digunakan sebesar-besarnya untuk kemakmuran rakyat.

Pertambangan merupakan industri yang diandalkan pemerintah Indonesia dalam mendatangkan sumber devisa dan Pendapatan Asli Daerah (PAD). Untuk itu keberadaanya industri pertambangan harus dikeola dengan benar disamping setiap industri pertambangan itu sendiri selalu berurusan dengan masalah lingkungan dan tidak akan lepas dari eksplorasi, eksploitasi, pengelolaan /pemurnian pengangkutan mineral/bahan tambang.

Namun dalam implementasinya, negara seringkali dihadapkan pada kondisi dilematis 
antara pemanfaatan optimal dengan kerugian lingkungan dan sosial, termasuk menyeimbangkan pertumbuhan dengan pemerataan. Refleksi saat ini adalah penguasaan oleh negara lebih mendominasi pemanfaatannya, sehingga perlu penyeimbangan baru berupa pengelolaan kebijakan nasional.

Mengingat mineral dan batu bara sebagai kekayaan alam yang terkandung di dalam bumi merupakan sumber daya alam yang tidak terbarukan, pengelolaannya perlu dilakukan seoptimal mungkin, efisien, transparan, berkelanjutan dan berwawasan lingkungan, serta berkeadilan agar memperoleh manfaat sebesar-besarnya bagi kemakmuran rakyat secara berkelanjutan. ${ }^{1}$

Tata cara penambangan yang benar akan besar pengaruhnya terhadap kegiatan usaha penambangan. Diharapkan kegiatan usaha penambangan yang benar akan lebih ekonomis dan efisien serta keamanan para pekerja dan lingkungan terjamin.

Kini dengan adanya UndangUndang Nomor 4 Tahun 2009 tentang pertambangan Mineral dan Batu Bara (untuk selanjutnya disebut UU Minerba), diperkenalkan Izin Usaha Pertambangan di Wilayah Izin Usaha Pertambangan (WIUP) dan tidak dipergunakan lagi perjanjian Kontrak Karya bagi Investor Pertambangan Umum yang mengajukan izin usaha pertambangan umum. $^{2}$ Berlakunya Undang-Undang Nomor 23 Tahun 2014 Tentang Pemerintah Daerah (untuk selanjutnya disebut UU Pemda), memberikan kewenangan pengeolaansumber daya khususnya pertambangan kepada pemerintah pusat dan pemerintah provinsi. Provinsi memegang kendali atas izin dan pengawasan terhadap galian c.

Di Jawa timur telah diatur di

dalam Peraturan Gubernur Jawa Timur Nomor 49 Tahun 2016 Tentang Pedoman Pemberian Izin Bidang Energi dan Sumber Daya Mineral di Jawa Timur (untuk selanjutnya disebut Pergub Jatim ESDM). Perizinan tidak langsung jadi melainkan melalui tahapantahapan sesuai prosedur. Dalam Peraturan Gubernur tersebut juga ada tata cara mengajukan izin. Meskipun telah di berlakukannya Pergub Jatim ESDM masih banyak pelaku usaha tambang yang tidak memiliki izin dan memanfaatkan bahan galian tersebut dengan semena-mena. Karena pemerintah kabupaten atau kota sendiri tidak memiliki wewenang untuk melakukan pengawasan terhadap penambangan liar atau ilegal di wilayahnya. Sehingga banyak penambang liar atau ilegal yang merusak ekosistem atau lingkungan di wilayah yang terkena dampak penambangan.

Hal yang seringkali dialami dalam praktik di lapangan adalah banyaknya penambang dalam melakukan kegiatan usaha tambangnya berdampak rusaknya lingkungan di sekitarnya. Karena tidak bisa dilakukan tindakan oleh Pemerintah Kabupaten/Daerah. Banyak masyarakat yang mengeluh dengan adanya penambangan ilegal 
yang merusak jalan pedesaan di akibatkan karena adanya alat-alat berat yang sering melintas di jalan pedesaan tersebut. Banyak juga terjadinya kecelakaan karena rusaknya jalan akibat kegiatan penambangan tersebut.

Susahnya tindakan penertiban pertambangan secara langsung karena pemerintah Kabupaten/Kota tidak bisa melakukan tindakan. Sesuai dengan UU Pemda nomor 23 tahun 2014 pasal 14 ayat 1 dan Permen ESDM pasal 43 dan 44. Salah satu kejadian yang terjadi di Desa Batu Kerbau, Kecamatan Pelepat, Bungo, Jambi. Terajdi penusukan terhadap Kapolsek dan Penyaderaan terhadap 7 polisi.

Peristiwa penusukan dan penyanderaan aparat kepolisian bernula saat mereka melakukan razia penambangan emas tanpa izin (PETI) di Kabupaten Bungo. Mengacu informasi dan media sosial, tim gabungan dari Polres Bungo dan Polsek Pelepat mengecek lokasi. ${ }^{3}$

Dari uraian masalah di atas, membuat peneliti tertarik untuk membuat penelitian yang berjudul "Pengawasan Tambang Galian C Di Kabupaten Gresik Di Tinjau Dari Pasal 14 ayat (1) Undang-Undang Nomor 23 Tahun 2014 Tentang Pemerintah Daerah dan Peraturan Menteri Energi dan Sumber Daya Mineral Nomor 26 Tahun 2018". issu hukum yang dihadapi. Penelitian hukum normatif dilakukan untuk mencari pemecahan masalah atas issu hukum (legal issue) yang ada. Dalam penelitian ini, peneliti melakukan penelitian tentang bagaimana hukum digunakan untuk dijadikan instrumen penegakan dan penerapan mekanisme pengawasan dan penindakan terhadap penambangan galian $\mathrm{c}$ dan dampak kerusakan lingkungan di Kabupaten Gresik. $^{4}$

\section{B. METODE PENELITIAN}

Jenis penelitian yang digunakan dalam penelitian ini menggunakan penelitian Normatif. Penelitian hukum Normatif adalah penelitian hukum untuk menemukan aturan hukum, prinsip-prinsip hukum, maupun doktrin-doktrin hukum guna guna menjawab 
Di dalam penelitian hukum terdapat beberapa pendekatan. Dengan pendekatan tersebut, peneliti akan mendapat informasi dari berbagai aspek mengenai isu yang sedang dicoba untuk dicari jawabannya. Adapun pendekatan penelitian tersebut adalah: ${ }^{5}$ pendekatan perundang-undangan, pendekatan konseptual, pendekatan sejarah, dan pendekatan perbandingan. Sumber bahan hukum primer merupakan bahan hukum yang bersifat autoritatif, artinya mempunyai otoritas. Bahan-bahan hukum primer terdiri dari perundang-undangan, catatan-catatan resmi atau risalah dalam pembuatan perundang-undangan dan putusanputusan hakim. Untuk bahan hukum primer yang berupa perundangundangan, yang memiliki otoritas tertinggi adalah Undang-Undang Dasar karena semua peraturan di bawahnya baik isi maupun jiwanya tidak boleh bertebtangan UUD tersebut. ${ }^{6}$ Sumber bahan hukum sekunder merupakan semua publikasi tentang hukum yang merupakan dokumen-dokumen resmi. Publikasi tentang hukum meliputi buku-buku teks, kamus-kamus hukum, jurnaljurnal hukum, dan komentarkomentar atas putusan pengadilan. ${ }^{7}$ Bahan hukum Tersier adalah bahan bahan hukum yang berfungsi untuk mendukung bahan primer dan bahan sekunder. Bahan hukum tersier terdiri dari kamus, kamus hukum dan ensiklopedia. ${ }^{8}$

\section{HASIL PENELITIAN DAN PEMBAHASAN}

\section{Kewenangan Pemerintah Kabupaten/Kota Dalam Otonomi Darah}

Undang-undang nomor 23 tahun 2014 tentang Pemerintahan Daerah menyatakan bahwa Negara Kesatuan Republik Indonesia dibagi atas daerah Provinsi, Kabupaten dan kota yang terdiri atas kecematan, kelurahan dan atau desa.

Daerah Provinsi selain berstatus sebagai daerah juga merupakan wilayah administrasi yang menjadi wilayah kerja bagi Gubernur sebagai wakil pemerintah pusat dan wilayah kerja Gubernur dalam menyelenggarakan urusan pemerintahan umum di wilayah daerah Provinsi. Dengan demikian nampak bahwa di dalam daerah Provinsi diberlakukan asas desentralisasi yang melahirkan daerah asas dekonsentrasi yang melahirkan wilayah administrasi dan tugas pembantuan yang melahirkan wilayah kerja khusus untuk penyelenggaraan urusan pemerintahan umum. Jadi ketiga asas tersebut dilaksanakan secara bersamaan di dalam daerah Provinsi. ${ }^{9}$

Di dalam Undang-undang nomor 23 tahun 2014 tentang 
Pemerintahan Daerah juga menyatakan bahwa ditariknya kembali kewenangan daerah Kabupaten/Kota dalam penyelenggaraan energi dan sumber daya mineral seperti pola penyelenggaraan yang selama ini dianut. Penyelenggaraan urusan pemerintahan pilihan terkait energi dan sumber daya mineral dibagi hanya antara pemerintah pusat dan daerah Provinsi saja. Pemerintah Kabupaten/Kota hanya dapat mengelola pemanfaatan langsung panas bumi. Sehingga pemerintah Kabupaten Gresik tidak memilikikewenangan untuk mengelolasumber daya mineral yang ada.

\section{Kasus posisi}

Di Indonesia terdapat banyak kekayaan alam salah satunya dalam sektor pertambangan. Hasil tambang mineral bukan logam salah satu hasil pertambangan yang ada di Indonesia atau biasa disebut dengan galian c. Kabupaten Gresik merupakan salah satu Kabupaten di Jawa Timur dengan kontur tanah pegunungan kapur yang mengandung banyak potensi tambang galian C. Tidak mengherankan banyak tambang baik legal maupun ilegal berada di Gresik. Terlebih minimnya pengawasan terhadap pertambangan termasuk pada pertambangan tradisional yang banyak dilakukan masyarakat.

Salah satu potensi tambang terbesar di Kabupaten Gresik adalah tambang Batu Onix yang ada di Kecamatan Sangkapura, Bawean. Selain batu onix, masyarakat di Kabupaten Gresik juga banyak sekaliyang memanfaatkan hasil tambang dari pegunungan kapur seperti bouksit, dolomite, magnesium, batu kapur dan tanah liat dan tanah urug Kawasan pertambangan yang telah dipetakan dalam Peraturan Daerah Nomor 8 tahun 2011 tentang Rencana Tata Ruang Wilayah Kabuaten Gresik tahun 2011-2030 tersebut tersebar di wilayah Utara Kabupaten Gresiik yaitu Bungah, Sidayu, Dukun, Ujungpangkah dan Panceng. Sementara di wilayah Selatan Gresik, lahan pertambangan tersebar di wilayah Kecamatan Wiringinanom, Kecamatan Kedamean dan Kecamatan Driyorejo.

Pengawasan pertambangan sebelumnya yang di pegang oleh pemerintah Kabupaten/Kota sekarang tidak ada lagi. Semenjak berlakunya Undang-Undang Nomor 23 Tahun 2014 Tentang Pemerintah Daerah pasal 14 ayat 1 semua pengawasan dan pengurusan izin berada di pemerintahan Provinsi. Sehingga peraturan daerah (untuk selanjutnya disebut perda) atau peraturan Bupati (untuk selanjutnya disebut perbup) mengenai petambangan yang ada di daerah tidak berlaku lagi dalam istilah biasa di sebut "Lex Superior Derogat Lego Inferior" yang artinya Hukum yang kedudukannya lebih tinggi menghapus hukum yang ada di bawahnya.

Semakin banyak pertambanganyang tidak mempunyai ijin atau pertambangan liar dikarenakan pemerintah Kabupaten/Kota tidak mempunyai wewenang untuk melakukan tindakan terhadap pelanggaran pertambangan tersebut. Kewenangan tersebut sekarang di pegang penuh oleh Pemerintah Provinsi semenjak berlakunya UndangUndang Nomor 
23 Tahun 2014 Tentang Pemerintah daerah. Melonjaknya pelanggar pertambangan karena pemerintah Provinsi tidak sepenuhnya bisa mengawasi pertambangan tersebut karena jumlah sumber daya manusia dan faktor wialayah yang sangat luas untuk langsung bisa melakukan tindakan terhadap pelanggar.

\section{Pertimbangan Hukum}

Pasal 14 ayat (1) UndangUndang Nomor 23 Tahun 2014 Tentang Pemerintah Daerah menyatakan bahwa penyelenggaraan urusan pemerintahan bidang kehutanan, kelautan, serta energi dan sumber daya mineral dibagi antara Pemerintah Pusat dan Daerah Provinsi. Dalam lampiran menyatakan bahwa pemerintah daerah hanya dapat mengelola pemanfaatan panas bumi dalam daerah Kabupaten/Kota sedangkan di Kabupaten Gresik tidak ada.

Pasal 43 ayat (1) Peraturan Menteri Energi dan Sumber Daya Mineral Nomor 26 Tahun 2018 Tentang Pelaksanaan Kaidah Pertambangan Yang Baik dan Pengawasan Pertambangan Mineral dan Batubara Menyatakan Bahwa penyelenggaraan pengelolaan uasaha pertambangan dilakukan oleh Menteri atau Gubernur sesuai dengan kewenangannya. Pasal 44 ayat (1) Menteri melakukan pengawasan terhadap penyelenggaraan pengelolaan usaha prtambangan yang dilaksanakan oleh Gubernur.

Berlakunya Undang-Undang Nomor 23 Tahun 2014 Tentang Pemerintah Daerah dan Peraturan Menteri Energi dan Sumber Daya Mineral Tentang Pelaksanaan Kaidah Pertambangan Yang Baik dan
Pengawasan Pertambangan Mineral dan Batubara Pengawasan tambang galian c sepenuhnya di pegang oleh pemerintah Provinsi sehingga pemerintah Kabupaten atau Kota tidak memiliki wewenang untuk melakukan tindakan terhadap galian c yang tidak memiliki izin.

\section{Legal Opinion}

Dengan berlakunya Peraturan Menteri Energi dan Sumber Daya Mineral pengawasan yang sepenuhnya dipegang oleh pemerintah Provinsi sangat tidak efektif karena luasnya wilayah tambang yang ada di Provinsi Jawa Timur dan kurangnya sumber daya manusia dalam mengawasi semua tambang galian $\mathrm{c}$ yang ada di Provinsi Jawa Timur.Sehingga banyak para pelaku tambang galian c yang tidak memiliki izin atau penambang ilegal. Pemerintah Kabupaten sendiri pun tidak bisa melakukan tindakan karena tidak memiliki kewenangan terhadap penambangan liar tersebut.

Oleh karena itu, penarikan kewenangan pengelolaan pertambangan galian $\mathrm{C}$ oleh pemerintah yang diberikan kepada pemerintah Provonsi menyebabkan permasalahan-permasalahan semakin bertambah dan dampak kerugiannya dirasakan langsung oleh Pemerintah Daerah. Pertama, dampak yang terjadi adalah infrastruktur jalan dan jembatan yang dilalui oleh truk-truk pengangkut bahan galian $\mathrm{C}$ menjadi lebih cepat rusak belum lagi adanya kecelakaan yang diakibatkan oleh jalan yang rusak oleh akibat aktivitas pertambangan. Kedua, legitimasi masyarakat daerah yang memiliki harapan kepada pemerintah daerah 
terkait pengelolaan pertambangan menurun. Penurunan legitimasi tersebut disebabkan masih banyaknya masyarakat yang tidak mengetahui pemerintah daerah tidak memiliki wewenang dalam pengelolaan pertambangan. Ketiga, terjadinya kerusakan lingkungan yang diakibatkan oleh aktifitas peratambangan tersebut karena tidak adanya reklamasi. Keempat, perekonomian daerah yang seharusnya dapat terbantu oleh pengelolaan pertambangan galian $\mathrm{C}$ tidak terwujud. Apabila pengelolaan pertambangan galian $\mathrm{C}$ masih dikuasai pemerintah daerah, maka pemerintah daerah dapat memanfaatkannya untuk pembanguan infrastruktur. Misalnya saja, perbaikan jembatan dan jalan yang rusak akibat dilalui oleh truktruk pengangkut bahan galian $\mathrm{C}$ tersebut. Dengan demikian, UndangUndang Nomor 23 Tahun 2014 Tentang Pemerintah Daerah dalam implementasinya yang membagi urusan pemerintahan terhadap pemerintah pusat, pemerintah provinsi, dan pemerintah daerah terkait pertambangan mengalami dampak yang merugikan pemerintah daerah.

Implementasi kebijakan pengelolaan pertambangan yang dilakukan setelah berlakunya Undang-Undang Nomor 23 Tahun 2014 tentang Pemerintahan Daerah dapat mengakibatkan timbulnya konflik atau paling tidak dapat menjadi disharmoni hubungan antara pemerintah Kabupaten dengan Pemerintah Provinsi/Pusat. Apalagi bila Kabupaten/Kota tersebut memiliki banyak potensi sumber daya alam dan skema bagi hasil dirasakan tidak cukup memadai. Maka akan menjadi pemicu timbulnya konflik yang semakin besar. Apabila tidak hati-hati dan cermat dalam pengelolaan dan pemanfaatan sumber daya alam yang secara kewilayahan berada pada wilayah Kabupaten/Kota yang tidak memperhatikan asas keadilan dan pemerataan. Dikhawatirkan akan timbul sentimen kedaerahan yang berlebihan dan terjadi konflik kepentingan yang tentunya akan berdampak tidak baik bagi upaya pembangunan daerah dan pembangunan nasional.

Kewenangan Pemerintah Kabupaten/Kota Dalam Hal Pertambangan Dan Tanggung Jawab Kerusakan Lingkungan

Kewenangan pemerintah Kabupaten/Kota terhadap kegiatan pertambangan menurut UndangUndang nomor 23 tahun 2014 tentang Pemerintah Daerah yang disahkan tanggal 30 September 2014 telah mengalami pergeseran kewenangan dalam hal mengeluarkan kewenangan penerbitan izin usaha pertambangan dan pengawasan terhadap kegiatan pertambangan. Sumber daya mineral logam, mineral bukan logam dan batuan dalam wilayah pertambangan yang sekarang menjadi kewenagan pemerintah provinsi.

Tetapi berdasarkan pasal 8 Undang-Undang Nomor 4 Tahun 2009 Tentang Pertambangan Mineral dan Batubara kewenangan pemberian izin usaha pertambangan untuk sumber daya mineral logam, batubara, mineral bukan logam dan batuan dalam wilayah pertambangan meupakan kewenangan pemerintah 
Kabupaten/Kota. Dengan demikian setelah berlakunya Undang-Undang Nomor 23 Tahun 2014 tentag Pemerintahan Daerah maka pemerintah Kabupaten/Kota seharusnya tidak lagi diperbolehkan mengeluarkan ijin baru baik berkaitan dengan petambangan air bawah tanah dan ijin lainnya yang berkaitan dengan pertambangan. Permasalahannya adalah bahwa Undang-Undang Nomor 4 Tahun 2009 Tentang Pertambangan Mineral dan Batubara sampai sekarang belum dicabut sehingga ada ketidak sinkronnya peraturan yang mengatur tentang kewenangan pemrintah daerah dalam menerbitkan ijin usaha pertambangan.

Inkosistensi antara UndangUndang Nomor 4 Tahun 2009 Tentang Pertambangan Mineral dan Batubara dan Undang-Undang Nomor 23 Tahun 2014 Tentang Pemerintah Daerah adalah pertentangan antara peraturan perundang-undangan yang sederajat hierarki. Konflik ketentuan UndangUndang Nomor 23 tahun 2014 dengan Undang-Undang Nomor 4 Tahun 2009 tersebut merupakan inkositensi dari segi substansi peraturan yakni peraturan yang secara hierarkis sejajar tetapi substansi peraturan yang satu lebih umum dibandingkan substansi peraturan lainnya. ${ }^{10}$

Apabila terdapat inkositensi norma menurut ilmu hukum antara sesama peraturan perundangundangan seperti ini maka ketentuan yang digunakan adalah asas lex specialis derogat legi generali mengandung makana bahwa aturan hukum yang khusus akan mengesampingkan aturan hukum yang umum. Sinkronisasi peraturan perundang-undangan dengan asas lex specialis derogat legi generali. Merujuk pada dua perturan perundang-undangan yang secara hierarkis mempunyai kedudukan yang sama, tetapi ruang lingkup materi muatan antara peraturan perundang -undangan itu tidak sama, yaitu yang satu merupakan pengaturan secara khusus dari yang lain. ${ }^{11}$

Kasus pencemaran atau kerusakan lingkungan semakin marak terjadi sehingga memerlukan penanganan secara terpadu, menyeluruh dan berkesinambung. Di Kabupaten Gresik banyak sekali kerusakan lingkungan yang diakibatkan aktifitas eksploitasi pertambangan. Banyak korban yang meninggal akibat eksploitasi pertambangan yang tidak melakukan reklamasi. Salah satu kejadian yang berada di Desa Suci Kecamatan Manyar ada sebanyak 6 orang meninggal karena tenggelam di kubangan bekas galian tambang yang tidak direklamasi dan kejadian yang sama ada di Kecamatan Sidayu seorang meninggal karena tenggelam di kubangan bekas tambang galian yang tidak direklamasi. Pengusaha pertambangan jarang sekali mau melakukan reklamasi pasca tambang karena di dalam pengurusan izin 
usaha pertambangan sudah dikenai uang retribusi jaminan untuk dilakukan reklamasi pasca tambang. Sehingga banyak pelaku usaha tambang menghiraukan untuk melakukan reklamasi pasca tambang karena sudah adanya uang jaminan untuk dilakukannya reklamasi pasca tambang. Hukum lingkungan dibuat dengan tujuan untuk melindungi lingkungan dan memberi mafaat kepada masyarakat artinya peraturan tersebut dibuat untuk kepentingan masyarakat. Hukum lingkungan menetapkan ketentuan dan normanorma guna mengatur tindakan perbuatan manusia dengan tujuan untuk melindungi lingkungan mutu serta menjamin kelestariannya agar dapat secara langsung digunakan oleh generasi sekarang maupun generasi yang akan datang.

Di Kabupaten Gresik kerusakan lingkungan yang terjadi banyak yang diakibatkan oleh kegiatan pertambangan. Karena pemerintah kabupaten tidak memiliki kewenangan untuk menindak terhadap pelanggar pertambangan yang merusak lingkungan. Sudah dijelaskan sebelumnya bahwa yang bertanggung jawab adalah pemerintah Provini. Dinas Provinsi terkait lingkungan dan pertambangan lah yang berhak untuk melakukan penindakan terhadap para pelanggar yang merusak lingkungan. Kerusakan lingkungan terjadi karena para pelaku tambang sering menghiraukan untuk melakukan reklamasi pasca tambang. Di dalam lapangan Penambang yang memiliki izin sering untuk tidak melakukan reklamasi pasca tambang apalagi para pelaku penambang yang tidak memiliki izin/illegal mining dikarenakan kurangnya pengawsan dari pemerintah terhadap aktifitas pertambangan tersebut.

\section{KESIMPULAN SARAN}

\section{Kesimpulan}

Berlakunya Undang-Undang Nomor 23 Tahun 2014 Tentang Pemerintah Daerah dan Peraturan Menteri Energi dan Sumber Daya Mineral Nomor 26 Tahun 2018 Tentang Pelaksanaan Kaidah Pertambangan Yang Baik dan Pengawasan Pertambangan Mineral dan Batubara Pengawasan tambang galian c sepenuhnya di pegang oleh pemerintah Provinsi sehingga pemerintah Kabupaten atau Kota tidak memiliki wewenang untuk melakukan tindakan terhadap galian c yang tidak memiliki izin. Oleh karena itu, penarikan kewenangan pengelolaan pertambangan galian $\mathrm{C}$ oleh pemerintah yang diberikan kepada pemerintah Provonsi menyebabkan permasalahanpermasalahan semakin bertambah dan dampak kerugiannya dirasakan langsung oleh Pemerintah Daerah.

$$
\text { Sesuai Undang-Undang }
$$

Nomor 32 Tahun 2009 Tentang Perlindungan dan Pengelolaan Lingkungan Hidup pasal 87 kerusakan lingkungan akibat aktivitas pertambangan adalah tanggung jawab pelakasana pertambangan, yang diikat melalui uang retribusi jaminan reklamasi. Pemerintah bertanggung jawab dalam pengawasan lingkungan hidup.

\section{Saran}

Pengawasan dan penindakan yang cepat dan responsif bagi 
pelanggar pertambangan mineral batuan. Penarikan kewenangan yang dilakukan harusnya tidak sampai ditingkat pengawasan dan penindakan. Pengawasan dan penindakan lebih baiknya berada pada wilayah pemerintah Kabupaten/Kota karena akan memempercepat aksi untuk penindakan terhadap pelanggar. Bersama dengan dinas Energi dan Sumber Daya Mineral sebagai perwakilan pemerintah Provinsi. Sehingga tidak menimbulkan kerugian negara dan kerusakan lingkungan.

Pemerintah Daerah mengintensifkan pengawasan terhadap kerusakan tambang dan menyuluh agar pengusaha melaksanakan rekondisi dan reklamasi pada lahan bekas galian guna menghindari kerusakan lingkungan.

\section{DAFTAR BACAAN}

\section{Buku-buku}

Hayati, Tri, "Era Baru Hukum Pertambangan Di Bawah Rezim UU No.4 Tahun 2009”, Cet.I, Yayasan Pustaka Obor Indonesia, Jakarta, 2015.

Marzuki, Peter Mahmud, "Penelitian Hukum”, Kencana, Jakarta, 2005.

Sukiyat, Suyanto, dan Prihatin Effendi, "Pedoman Penulisan Tugas Akhir", Jakad Media Publishing, Surabaya, 2019.

Sutedi, Adrian, "Hukum

Pertambangan", Cet.II, Sinar Grafika, Jakarta, 2012.

Peraturan perundang-undangan

Undang-Undang Dasar Negara
Republik Indonesia Tahun 1945.

Undang-Undang Nomor 23 Tahun 2014 Tentang Pemerintahan Daerah (Lembaran Negara Republik Indonesia Nomor 244 Tahun 2014, Tambahan Lembaran Negara Republik Indonesia Nomor 5587).

Undang-undang Nomor 4 Tahun 2009 Tentang Pertambangan (Lembaran Negara Republik Indonesia Nomor 4 Tahun 2009, Tambahan Lembaran Negara Republik Indonesia Nomor 4959).

Undang-Undang Nomor 32 Tahun 2009 Tentang Perlindungan dan Pengelolaan Lingkungan Hidup (Lembaran Negara Republik Indonesia Nomor 140 Tahun 2009, Tambahan Lembaran Negara Republik Indonesia Nomor 5059).

Peraturan Pemerintah Nomor 23 Tahun $2010 \quad$ Tentang Pelaksanaan Kegiatan Usaha Pertambangan Mineral dan Batu Bara (Lembaran Negara Republik Indonesia Nomor 29 Tahun 2010, Tambahan Lembaran Negara Republik Indonesia Nomor 5111).

Peraturan Pemerintah Nomor 22 Tahun $2010 \quad$ Tentang Wilayah Pertambangan (Lembaran Negara Republik Indonesia Nomor 28 Tahun 2010, Tambahan Lembaran Negara Republik Indonesia Nomor 5110).

Peraturan Menteri Energi Dan Sumber Daya Mineral Nomor 26 Tahun 2018 
Jurnal Pro Hukum: Vol . 10, No. 1, 2021

Tentang Pelaksanaan
Kaidah Pertambangan Yang
Baik dan Pengawasan
Pertambangan Mineral dan
Batubara (Berita Negara
Republik Indonesia Nomor
596 Tahun 2018).
Peraturan Gubernur Jawa Timur
Nomor 49 Tahun 2016
Tentang
Pemberian Izin Pedoman
Energi dan Sumber Daya
Mineral di Jawa Timur
(Berita Daerah Provinsi
Jawa Timur Nomor 49 Seri
E Tahun 2016).

Tesis-tesis

Isnaeni, Diyan, "Implikasi Yuridis Kewenangan Pemerintah Daerah Dalam Pemberian Ijin Usaha Pertambangan Menurut Undang-Undang Nomor 23 Tahun 2014", Fakultas Hukum Universitas Islam Malang,Malang, 2018

Media Daring.

Pythag Kurniati. "Kasus Penusukan Polsek Dan Penyanderaan 7 Polisi, Polda Jambi Belum Tetapkan Tersangka", Kompas (online). Diunggah Tanggal 14 Mei 2020, https://regional.kompas.com re $\underline{\mathrm{ad} / 2020 / 05 / 14 / 08402161 / \mathrm{ka}}$ $\underline{\text { sus }}$ -penusukan-kapolsek-danpenyanderaan-7-polisipolda-jambi-belum 